\title{
Promocija mentalnog zdravlja i prevencija mentalnih poremećaja kod djece i adolescenata - sistematičan pregled literature
}

1 Sanja Ledinski Fičko

1 Snježana Čukljek

1 Martina Smrekar

1 Ana Marija Hošnjak

1 Katedra za zdravstvenu njegu, Zdravstveno veleučilište Zagreb

\section{SAŽETAK}

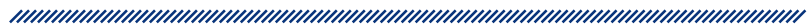

Cilj: Pojavnost mentalnih poremećaja u porastu je kod djece i adolescenata te predstavlja velik izazov za javnozdravstvenu zaštitu. Poremećaji su mentalnog zdravlja brojni te obuhvaćaju pojavu depresije, intelektualnih poteškoća, rizičnog ponašanja i dr., a prema zadnjim podatcima 10 do $20 \%$ djece i adolescenata ima neku vrstu mentalnog poremećaja. Cilj je rada pregledom dostupne znanstvene literature proučiti metode promocije mentalnog zdravlja kod djece i adolescenata.

Metode: Sistematičan pregled literature temelji se na pregledu dostupnih znanstvenih radova. Radovi koji su ušli u zadnju fazu obrade objavljeni su kao sistematičan pregled literature i istraživački rad, izvedeni su iz baze podataka MEDLINE te su pisani na engleskom jeziku.

Rezultati: Brojni nacionalni programi provode se u cilju promocije mentalnog zdravlja djece i adolescenata, no bez obzira na implementaciju programa u sustav, i dalje je visoka pojavnost mentalnih poremećaja u toj dobi. Važno je pojačati suradnju primarne zdravstvene zaštite i specijalista te usmjeriti specifične intervencije s obzirom na rizične faktore koji se javljaju.

Zaključak: Promocija mentalnog zdravlja djece i adolescenata osigurava adekvatan rast i razvoj te stvara temelj budućih generacija. Programi prevencije moraju se provoditi sustavno, dosljedno i moraju osiguravati holistički pristup. S obzirom na sve veću pojavnost mentalnih poremećaja u djece i adolescenata, važna je kako njihova edukacija tako i edukacija roditelja. Unaprijed izrađeni planovi prevencije omogućuje direktno djelovanje na rizične čimbenike.

Ključne riječi: mentalno zdravlje, prevencija, promocija, djeca i adolescenti, rizični faktori

Datum primitka: 07.11.2016.

Datum prihvaćanja: 01.06.2017.

DOI: $10.24141 / 3 / 1 / 7$

Adresa za dopisivanje:

Sanja Ledinski Fičko

Zdravstveno veleučilište Zagreb

Mlinarska cesta 38, 10000 Zagreb, Hrvatska

E-pošta: sanja.ledinski-ficko@zvu.hr

Tel.: + 385914595713 


\section{UVOD}

Mentalno je zdravlje integralna i esencijalna komponenta zdravlja te podrazumijeva cjelovito fizičko, mentalno i socijalno blagostanje, a ne samo odsutnost bolesti i nemoći. Mentalno zdravlje pojedincu omogućuje ostvarenje vlastitih potencijala, produktivnost u radu, mogući doprinos zajednici u kojoj živi te adekvatno suočavanje sa svakodnevnim stresnim situacijama. Psihološki, socijalni i biološki faktori imaju znatan utjecaj na mentalno zdravlje te razina njegova postignuća ovisi o trenutačnoj situaciji u kojoj se pojedinac nalazi. Način života koji nalaže brze društvene promjene, socijalnu izoliranost, nasilje, siromaštvo, stres u okolini, somatske bolesti i povrjeđivanje ljudskih prava najčešći su prediktori narušavanja mentalnog zdravlja. ${ }^{1}$

Prema statističkim podatcima Svjetske zdravstvene organizacije, 3 do $12 \%$ mladih ima ozbiljan psihički poremećaj, a $20 \%$ mladih u dobi do 18 godine ima neki od oblika razvojnih, emocionalnih ili ponašajnih problema. ${ }^{2}$ Statistički su podatci za Republiku Hrvatsku za 2011. godinu sljedeći: poremećaji kod osnovnoškolske djece rangirani su kao treći najčešći razlog posjeta liječniku školske medicine, čine $14 \%$ slučajeva, praćeni su rizičnim ponašanjem u $8 \%$ slučajeva. Srednjoškolska populacija također je rangirana kao treća, sa $12 \%$ slučajeva posjeta liječniku školske medicine, s rizičnim ponašanjem u $12 \%$ slučajeva. Mentalni i ponašajni poremećaji u 0,6\% slučajeva razlog su hospitalizacije u dobi od 0 do 4 godine, $1,2 \%$ u dobnoj skupini od 5 do 9 godina te $4,8 \%$ u dobnoj skupini od 10 do 19 godina. ${ }^{3}$

Ranije navedeni podatci ukazuju na potrebu promicanja mentalnog zdravlja i prevenciju nastanka mentalnih poremećaja. Na području Republike Hrvatske za razvoj i implementaciju Nacionalne strategije zaštite mentalnog zdravlja za razdoblje 2011. - 2016. odgovorno je Ministarstvo zdravlja Republike Hrvatske. Glavni su ciljevi Nacionalne strategije promocija mentalnog zdravlja, definiranje mentalnih poremećaja kroz preventivne aktivnosti, promocija ranog dijagnosticiranja i liječenja mentalnih poremećaja, poboljšanje kvalitete života osoba s mentalnim poremećajima kroz socijalnu integraciju, zaštita njihovih prava i dostojanstva, razvoj grupa za podršku i informiranje te povećanje znanja i provođenja istraživanja na području mentalnog zdravlja. ${ }^{3}$ Ciljevi su koji se odnose na djecu i adolescente promocija vještine roditeljstva i rana interakcija, razvijanje strategija suočavanja sa stresom s posebnim naglaskom kod djece koja imaju razvijenu mentalnu bolest, promicanje i razvoj programa za prevenciju nasilja te unaprjeđenje ranog dijagnosticiranja i intervencija intelektualnih poteškoća i potpora obitelji. Strateški plan razvoja javnog zdravstva 2013. - 2015. uključuje aktivnosti kao što su promocija zdravstvenog ponašanja kod djece školske dobi, prevencija konzumiranja alkohola, situacijska analiza i uspostava sustava probira na primarnoj zdravstvenoj zaštiti s posebnom pažnjom na depresiju i anksioznost.

Najčešći su uzroci hospitalizacije uzrokovani narušavanjem mentalnog zdravlja u dobi od 0 do 4 godine specifični poremećaji razvoja motoričkih funkcija, specifični miješani razvojni poremećaji, specifični poremećaji razvoja govora i jezika, umjerene intelektualne poteškoće, ostali poremećaji ponašanja i osjećaja koji se javljaju u djetinjstvu i adolescenciji. Najčešći su uzroci hospitalizacije uzrokovani narušavanjem mentalnog zdravlja u dobi od 5 do 9 godina specifični poremećaji razvoja govora i jezika, ostali poremećaji ponašanja i osjećaja koji se javljaju u djetinjstvu i adolescenciji, hiperaktivni poremećaji, pervazivni razvojni poremećaji te umjerene intelektualne poteškoće. Najčešći su uzroci hospitalizacije uzrokovani narušavanjem mentalnog zdravlja u dobi od 10 do 19 godina poremećaji ponašanja, mentalni poremećaji i poremećaji ponašanja uzrokovani alkoholom, akutni i prolazni mentalni poremećaji, mješoviti poremećaji ponašanja i osjećaja te shizofrenija.

Pojam prevencije odnosi se na postupke koji za cilj imaju sprječavanje nepovoljnih događaja. Razlikujemo tri razine djelovanja, a to su univerzalna ili opća prevencija koja je usmjerena na cijelu populaciju, selektivna prevencija koje je usmjerena na skupine populacije koje su pod povećanim rizikom u odnosu na opću populaciju te indicirana prevencija koja je usmjerena na prepoznavanje i djelovanje prema onim pojedincima kod kojih su se javila društveno neprihvatljiva ili osobno nepoželjna ponašanja. Prema dosadašnjim saznanjima, naglasak se stavlja na pravilnu identifikaciju rizičnih faktora te planiranje intervencija u cilju redukcije rizičnih faktora u rizičnoj skupini. ${ }^{4}$ Intervencije kod mlađe životne populacije posebno su usmjerene na redukciju novih slučajeva anksioznosti, depresije i poremećaj ponašanja. ${ }^{5}$

Cilj je rada pregledom dostupne znanstvene literature proučiti metode promocije mentalnog zdravlja kod djece i adolescenata. 


\section{METODE}

U cilju proučavanja promocije mentalnog zdravlja kod djece i adolescenata, određeni su sljedeći koraci:

1. sistematičan pregled literature izveden iz baze podataka MEDLINE te proučavanje stručne literature

2. pregled aktualnih programa promocije mentalnog zdravlja i prevencije mentalnih poremećaja.

\subsection{Sistematičan pregled literature}

Sistematičan pregled literature izvršen je u lipnju 2016. u bazi podataka MEDLINE za razdoblje od 2005. do 2016. godine. Raspon godina određen je kako bi se osigurao pregled novije literature na području promocije mentalnog zdravlja djece i adolescenata. Kombinacija pojmova koji su zadovoljili kriterije uključivanja, kao mogući metodološki filtar, bila je strategija pretraživanja.
Booleovim operatorima pojmovi su međusobno kombinirani („,and, or"): promotion of metal health and youth, promotion of metal health and adolescent, promotion of metal health and children (promocija metalnog zdravlja i mladi, promocija metalnog zdravlja i adolescenti, promocija mentalnog zdravlja i djeca). Prilikom pretraživanja, pojmovi za pretraživanje bile su ključne riječi na engleskom jeziku: mental health, promotion, prevention, children, youth, adolescent.

\subsubsection{Strategija pretraživanja}

U bazu podataka MEDLINE upisane su sljedeće ključne riječi na engleskom jeziku: mental health, promotion, prevention, children, youth, adolescent. Kod prvih rezultata pretrage odbačeni su radovi koji nisu odgovarali unaprijed određenom vremenu publikacije. Nakon toga su isključeni radovi koji su nisu napisani na engleskom jeziku. Nadalje su analizirani sažetci radova te konačno cijeli publicirani rad ako je odgovarao cilju istraživanja.
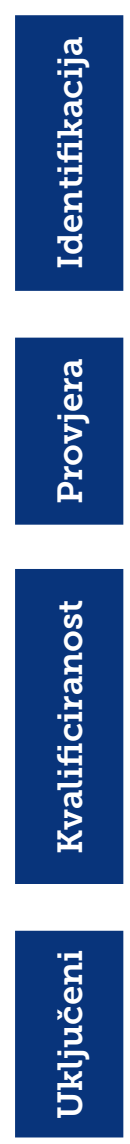

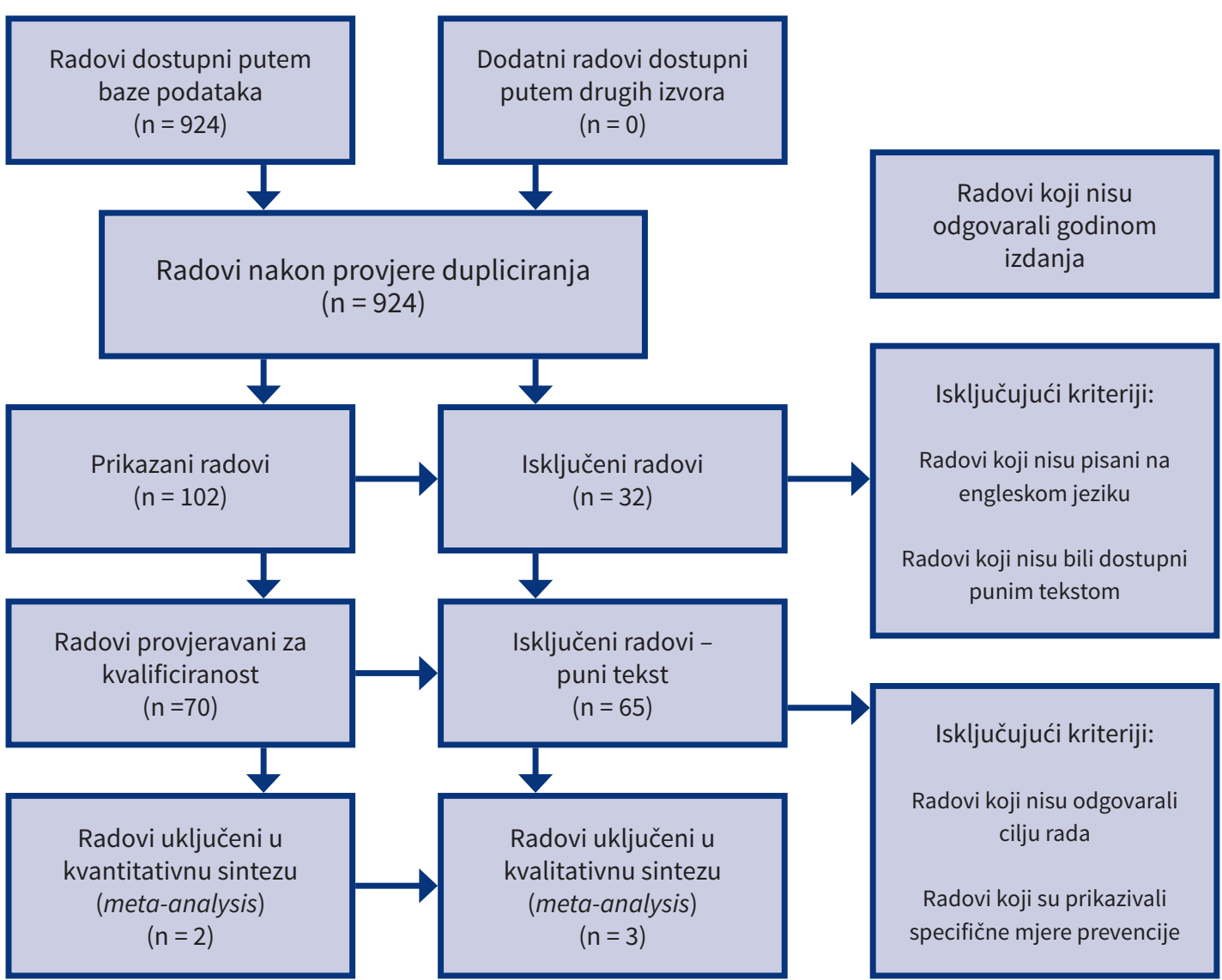

Dijagram 1. Prikaz pretrage i selekcije znanstvenih radova ${ }^{6}$ 


\subsubsection{Uključujući i isključujući kriteriji}

U konačnu analizu uključeni su svi radovi koji su sadržajno odgovarali postavljenim ciljevima. Radovi koji su uključeni omogućili su prikaz planova prevencije i promocije te rezultate njihove primjene. Svi radovi koji su uključeni napisani su na engleskom jeziku.

Iz istraživanja su isključeni radovi koji nisu napisani na engleskom jeziku, koji su se odnosili samo na jednu vrstu mentalnog poremećaja u djece i adolescenata te u skladu s time prikazivali specifične mjere prevencije samo za navedeni poremećaj te koji nisu bili dostupni punim tekstom.

\subsubsection{Konačna analiza}

Radovi koji su uključeni u konačnu analizu analizirani su kroz četiri koraka. U prvom su koraku odabrani članci koji su odgovarali naslovom s obzirom na ključne riječi upisane u znanstvene baze. $U$ drugom koraku analizirana je godina objave članka u rasponu godina od 2005. do 2016. U trećem koraku analizirani su sažetci radova koji su odgovarali naslovom, koji su dostupni punim tekstom i pisani na engleskom jeziku. $U$ četvrtom koraku izrađena je tablica u svrhu upisa podataka iz radova povezanih s ciljem rada, načinom provođenja istraživanja, karakteristikama ispitanika te rezultatima istraživanja.

U konačnu je analizu uključeno ukupno pet radova. Tri su rada napisana kao sistematičan prikaz literature, dok su dva rada napisana kao istraživački rad. Radovi su odabrani po kriterijima sustavnosti i cjelovitosti te holističkog pristupa prevenciji mentalnih poremećaja, vremenu i jeziku publiciranja. U konačnu su analizu uključeni radovi koji su prikazivali mjere prevencije za sve mentalne poremećaje djece i adolescenata te su prikazivali rezultate njihova provođenja. U konačnu analizu nisu uključeni radovi koji su se odnosili na samo jednu vrstu mentalnog poremećaja (prevencija depresije, suicida...) kod djece i adolescenata.

\subsection{Pregled aktualnih programa zaštite mentalnog zdravlja}

Prema Nacionalnoj strategiji zaštite mentalnog zdravlja za razdoblje od 2011. do 2016., u provođenju aktualnih programa zaštite mentalnog zdravlja u Republici Hrvatskoj sudjelovali su Ministarstvo zdravlja, Ministarstvo znanosti, obrazovanja i sporta, Ministarstvo socijalne politike i mladih, Ministarstvo zaštite okoliša i prirode, Ministarstvo graditeljstva i prostornog uređenja, Hrvat- ski zavod za javno zdravstvo, Ministarstvo unutarnjih poslova RH, Agencija za odgoj i obrazovanje, županijski zavodi za javno zdravstvo, jedinice lokalne i područne samouprave, zdravstvene ustanove, centri za socijalnu skrb, akademske institucije, stručna društva i mediji. Primarna je prevencija usmjerena smanjenju incidencije mentalnih poremećaja te podrazumijeva suzbijanje čimbenika rizika za razvoj mentalnih poremećaja, kao i jačanje zaštitnih čimbenika. Sekundarna je prevencija usmjerena smanjuju pojavnosti mentalnih poremećaja skraćivanjem njihova trajanja ranim otkrivanjem i adekvatnim liječenjem. Tercijarna je prevencija usmjerena smanjivanju težine bolesti i onesposobljenosti povezanih s određenim poremećajem, uključuje rehabilitaciju, skrb za kvalitetu života i mentalnog zdravlja te prevenciju samoubojstva.

S obzirom na navedene podatke važno je prepoznati rizične faktore koji dovode do narušavanja mentalnog zdravlja kako bi se pomoglo pojedincima od najranije dobi. Poznato je kako biološka predisponiranost, uključujući genetsko naslijeđe i disbalans na razini neurotransmitera, ima nepobitnu ulogu u pojavi mentalnih poremećaja. No brojni su i okolišni faktori koji utječu na mentalno zdravlje i normalno funkcioniranje pojedinca. Neki su od glavnih prediktora narušavanja mentalnog zdravlja siromaštvo i nizak stupanj obrazovanja te nasilje u obitelji. Rizični su faktori koji se također ističu kao važni prediktori narušavanju mentalnog zdravlja stres na poslu, brze društvene promjene, socijalna izolacija, spolna i rodna diskriminacija, somatske bolesti i povrjeđivanje ljudskih prava, nezdrav način života te nasilje.

\section{REZULTATI}

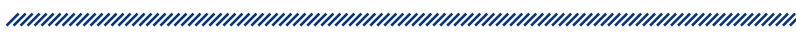

Prvi rezultati pretrage znanstvenih baza omogućili su dostupna 924 rada. U drugom koraku analizirana je godina objave članaka te je nakon toga ostalo dostupno 102 radova. U trećem koraku analizirani su radovi koji su odgovarali naslovom, koji su pisani na engleskom jeziku te koji su dostupni u punom tekstu. $U$ četvrtom koraku analizirani su radovi koji su prikazivali promociju mentalnog zdravlja i mjere prevencije mentalnih poremećaja u djece i adolescenata te je izrađena tablica u svrhu upisivanja podataka. Rezultati pretrage i selekcije prikazani su u dijagramu 1. Radovi uključeni 
Tablica 1. Tablični prikaz preventivnih programa u Hrvatskoj i susjednim zemljama članicama EU-a ${ }^{3}$

\begin{tabular}{|c|c|c|}
\hline DRŽAVA & $\begin{array}{c}\text { PREVENTIVNI I PROMOTIVNI PROGRAMI U } \\
\text { ŠKOLAMA }\end{array}$ & CILJ \\
\hline \multirow{12}{*}{ HRVATSKA } & Prevencija zloupotrebe droga u školama & $\begin{array}{l}\text { Edukacija, identificiranje problema i } \\
\text { povećavanje svjesnosti nastavnika }\end{array}$ \\
\hline & Prevencija depresije i suicida u gradu Zagrebu & Prevencija nastanaka mentalnih poremećaja \\
\hline & $\begin{array}{l}\text { Nacionalni program prevencije depresije i suicida u } \\
\text { djece i adolescenata }\end{array}$ & $\begin{array}{l}\text { Smanjivanje rizika od depresije, pokušaja } \\
\text { suicida i povećanje multisektorske suradnje } \\
\text { u prevenciji nastanka mentalnih poremećaja }\end{array}$ \\
\hline & UNICEF - stop nasilju među djecom & Prevencija nasilja \\
\hline & Hrabri telefon & Prevencija nasilja među djecom i mladima \\
\hline & Plavi telefon & Prevencija nasilja među djecom i mladima \\
\hline & Dokkica & $\begin{array}{l}\text { Promocija mentalnog zdravlja i prevencija } \\
\text { antisocijalnog ponašanja }\end{array}$ \\
\hline & Promotivni program „Ja sam lijepa” & Prevencija poremećaja prehrane \\
\hline & Projekt „Stranac u ogledalu” & Prevencija poremećaja prehrane \\
\hline & Projekt „Želim biti tvoj prijatelj” & $\begin{array}{c}\text { Promocija uključivanja djece s invaliditetom } \\
\text { u zajednicu }\end{array}$ \\
\hline & $\begin{array}{c}\text { Program „Zaštita mentalnog zdravlja djece unutar } \\
\text { obitelji s mentalnim problemima” }\end{array}$ & $\begin{array}{l}\text { Zaštita mentalnog zdravlja članova obitelji } \\
\text { koji su u suživotu s oboljelima od mentalnih } \\
\text { poremećaja }\end{array}$ \\
\hline & Projekt „Školski sat za emocije” & Promocija znanja o emocijama \\
\hline \multirow{2}{*}{ MAĐARSKA } & $\begin{array}{c}\text { Mađarska asocijacija za savjetovanje u visokoškolskom } \\
\text { obrazovanju }\end{array}$ & Promocija mentalnog zdravlja studenata \\
\hline & Holistički zdravstveni program u školama & $\begin{array}{l}\text { Promocija socijalnog, osobnog i } \\
\text { emocionalnog zdravlja i dobrobiti u školama }\end{array}$ \\
\hline \multirow{3}{*}{ ITALIJA } & Strategija prevencije za mlade u zajednici & $\begin{array}{c}\text { Razvijanje alata i implementacija aktivnosti } \\
\text { na području prevencije mentalnih } \\
\text { poremećaja mladih }\end{array}$ \\
\hline & Stjecanje zdravlja & $\begin{array}{l}\text { Promocija zdravog načina života, povećanje } \\
\text { razine dobrobiti za sve dobne skupine }\end{array}$ \\
\hline & $\begin{array}{l}\text { Internet i medijski pokrivena prevencija suicida } \\
\text { adolescenata }\end{array}$ & $\begin{array}{c}\text { Poboljšanje mentalnog zdravlja i dobrobiti } \\
\text { adolescenata }\end{array}$ \\
\hline \multirow{8}{*}{ AUSTRIJA } & KiVi & $\begin{array}{l}\text { Strukturirana promocija mentalnog zdravlja } \\
\text { u školama }\end{array}$ \\
\hline & Projekt „FeelOK” & $\begin{array}{c}\text { Program promocije mentalnog zdravlja } \\
\text { putem interneta }\end{array}$ \\
\hline & Projekt „Zdrava škola” & Jačanje mentalnog zdravlja djece \\
\hline & Projekt „Socijalna mreža u školama” & Redukcija izostanaka iz škole \\
\hline & Projekt „Bijelo pero” & $\begin{array}{l}\text { Pružanje roditeljima, djeci i nastavnicima } \\
\text { učinkovitih alata prevencije i intervencije }\end{array}$ \\
\hline & BMUKK & $\begin{array}{c}\text { Prevencija nasilja, ovisnosti i osiguranje } \\
\text { seksualnog odgoja }\end{array}$ \\
\hline & Projekt „Postajemo neovisni” & $\begin{array}{c}\text { Kombinacija osobnog razvoja, promocije } \\
\text { zdravlja, promocije životnih vještina i } \\
\text { prevencija ovisnosti i nasilja }\end{array}$ \\
\hline & Projekt „Osjećamo se dobro” & $\begin{array}{l}\text { Informiranje građana o različitim načinima } \\
\text { očuvanja mentalnog zdravlja }\end{array}$ \\
\hline
\end{tabular}


u analizu podataka prikazuju preventivne/promotivne mjere te njihov utjecaj na mentalno zdravlje. Radovi koji su uključeni u konačnu analizu sistematični su pregled literature, kao i dva istraživačka rada. Radovi su pisani na engleskom jeziku te su objavljeni u znanstvenim časopisima. Radovi koji su uključeni u analizu odabrani su po ranije navedenim kriterijima te su odabrani oni koji u svojem sadržaju obuhvaćaju preventivne mjere i rezultate njihova provođenja.

\subsection{Sinteza podataka}

Svih pet radova odnosi se na planove promocije mentalnog zdravlja kod djece i adolescenata. Rano prepoznavanje i terapija mentalnih poremećaja dovodi do poboljšanja kvalitete života oboljelih te povećava mogućnost potpunog oporavka. Odabrani radovi prikazani su i opisani u tablici 2.

Glavni je cilj programa zaštite mentalnog zdravlja opće populacije bolje sučeljavanje sa svakodnevicom te svladavanje kriznih situacija, nadalje rano otkrivanje i terapija djece i adolescenata s poremećajima ponašanja te rad s obiteljima i skrbnicima djece i adolescenata s problemima mentalnog zdravlja. Prema Nacionalnoj strategiji za prava djece Vlade $\mathrm{RH}$, djelatnost zdravstvenih službi trebala bi se temeljiti na načelima uključivanja, promicanja, zaštite, prevencije i usmjerenosti prema potrebama. ${ }^{12}$ Važna je senzibilizacija i edukacija djelatnika primarne zdravstvene zaštite za rano prepoznavanje poremećaja ponašanja i problema mentalnog zdravlja. Potrebno je jačati i razvijati jedinice za zaštitu mentalnog zdravlja koje bi na primarnoj razini pružale kontinuiranu, multidisciplinarnu skrb i podršku. ${ }^{12}$ Rad s nastavnim osobljem predškolskih i školskih ustanova u cilju ranog prepoznavanja, savjetovanje, individualna i grupna terapija za djecu i adolescente te uključivanje obitelji u terapijski proces od iznimne je važnosti. Uključivanje zdravstvenih djelatnika u provođenje zdravstvenog odgoja važan je korak u očuvanju mentalnog zdravlja mladih i adolescenata. Cilj je da se kroz različite kontakte pokuša prevenirati te rano prepoznati prisutnost mentalnih poremećaja kod djece i adolescenata. $U$ prevenciju se uključuju roditelji, odgojitelji, nastavnici i zdravstveno osoblje koje je u kontaktu s djecom i adolescentima. Važna je edukacija i savjetovanje o rizičnim čimbenicima te mogućim problemima s obzirom na dob, kao što je rizik za suicid, rizik od alkoholizma i slično. Važno je također praćenje svake promjene do koje su doveli programi promocije i prevencije, s obzirom na to da se smatra kako i najmanji pomak može imati veliki utjecaj na krajnji rezultat i širu populaciju. ${ }^{13-16}$
Patel i suradnici 2007. godine navode rizične faktore za nastanak mentalnih poremećaja te zaštitne faktore kod djece i adolescenata. ${ }^{7}$ Rizične su faktore podijelili na biološke, psihološke i socijalne. Biološki su faktori izloženost toksinima i drugim štetnim tvarima kao što su alkohol i nikotin, genetska predispozicija za nastanak mentalnih poremećaja, trauma glave, hipoksija kod poroda i druge poslijeporođajne komplikacije, infekcija HIV-om, malnutricija, upotreba opojnih sredstava te druge bolesti. Psihološki su faktori poremećaji učenja, seksualno, fizičko i emocionalno zlostavljanje, urođene osobine ličnosti i neke karakterne osobine. Socijalni se faktori dijele na obiteljske, školske i faktore iz zajednice. Obiteljski su faktori sukobi u obitelji, smrt člana obitelji i nekonzistentan odgoj djece. Faktori su iz školske okoline nasilje - buling, neuspjeh u školi te neuspjeh škole da pruži poticajnu i sigurnu okolinu. Faktori iz zajednice jesu diskriminacija, izloženost nasilju, narušeni društveni odnosi i preseljenje. ${ }^{7}$ Djeca i adolescenti koji imaju razvijene socijalne vještine, sposobnost rješavanja problema, sposobnost učenja iz vlastitih pogrešaka, dobro fizičko zdravlje, razvijeno samopoštovanje, obiteljsku podršku i pozitivne uzore imaju manju mogućnost za razvijanje mentalnih poremećaja.

Nakon određivanja rizičnih faktora važno je odrediti kako će se provoditi prevencija mentalnih poremećaja djece i adolescenata i tko će je provoditi. Cilj je djelovanjem na rizične faktore spriječiti nastanak mentalnih poremećaja, osigurati što brži oporavak oboljelih te omogućiti adekvatnu prilagodbu djece i mladih s trajnim poremećajima. Rizični su faktori koji se javljaju unutar obitelji maloljetnička trudnoća, siromaštvo, nizak stupanj obrazovanja, nesklad unutar obitelji (fizički i verbalni sukobi), razvod supružnika, samohrano roditeljstvo, niska kvaliteta života jednog ili oba roditelja (fizički i psihosocijalni aspekt) te pružena potpora i ljubav roditelja djetetu i problemi s alkoholom. Rizični su faktori unutar zajednice neprihvaćenost vršnjaka, izloženost nasilju i spolno zlostavljanje. Genetski se faktori odnose na nasljeđe i disbalans na razini neurotransmitera. Također je dokazana povezanost između pušenja i konzumiranja alkohola u trudnoći s nastankom mentalnih poremećaja u ranoj dječjoj dobi. ${ }^{17-24}$ Catania i suradnici navode da je važna suradnja između primarne zdravstvene zaštite i specijalista psihijatra i psihologa. Adekvatna suradnja omogućuje pripremu, osigurava dodatno vrijeme i pruža potporne strukture u programu prevencije. ${ }^{8}$ Predložene preventivne mjere pokazale su se kao efikasne komponente prevencije. Različiti su autori pregledom literature te provođenjem istraživanja 


\section{Tablica 2. Opis uključenih znanstvenih radova}

\begin{tabular}{|c|c|c|c|}
\hline Znanstveni rad & Opis & Predložene mjere & Rezultati \\
\hline $\begin{array}{l}\text { Patel V, Flisher AJ, Hetrick S, } \\
\text { McGorry P. Mental health of } \\
\text { young people: a global public- } \\
\text { health challenge. } 2007 .^{7}\end{array}$ & $\begin{array}{c}\text { Sistematični pregled } \\
\text { literature }\end{array}$ & $\begin{array}{l}\text { Psihosocijalna podrška, } \\
\text { strategije samopomoći, } \\
\text { edukacija, rana dijagnostika, } \\
\text { reforma javnozdravstvenih } \\
\text { programa, specifični tretman } \\
\text { prema vrsti poremećaja, } \\
\text { obiteljska terapija }\end{array}$ & $\begin{array}{l}\text { Bez obzira na edukaciju } \\
\text { mladih i roditelja o } \\
\text { mentalnom zdravlju, i dalje } \\
\text { postoji nerazmjer u količini } \\
\text { znanja koju bi trebali imali. } \\
\text { Stoga je zaključak kako se } \\
\text { jačanje mentalnog zdravlja } \\
\text { mora poticati unutar } \\
\text { obitelji. Važno je promicanje } \\
\text { fundamentalnih principa i } \\
\text { vrijednosti. }\end{array}$ \\
\hline $\begin{array}{c}\text { Catania LS, Hetrick SE, } \\
\text { Newman LK, Purcell R. } \\
\text { Prevention and early } \\
\text { intervention for mental health } \\
\text { problems in 0-25 year olds: Are } \\
\text { there evidence-based models } \\
\text { of care? 2011. }\end{array}$ & $\begin{array}{c}\text { Sistematični pregled } \\
\text { literature }\end{array}$ & $\begin{array}{l}\text { Pojačati suradnju između } \\
\text { primarne zdravstvene zaštite } \\
\text { i specijalista psihijatara }\end{array}$ & $\begin{array}{l}\text { Istraživanja su pokazala } \\
\text { kako je jača suradnja između } \\
\text { primarne zdravstvene } \\
\text { zaštite i specijalista dovela } \\
\text { do efikasnije prevencije i } \\
\text { liječenja djece i mladih s } \\
\text { mentalnim poremećajima. } \\
\text { Veća dostupnost sredstava i } \\
\text { dobra obiteljska atmosfera } \\
\text { zajedno sa jakom socijalnom } \\
\text { podrškom povezana je sa } \\
\text { smanjenjem pojavnosti } \\
\text { mentalnih poremećaja. }\end{array}$ \\
\hline $\begin{array}{l}\text { Flores } \mathrm{N} \text { et al. Prevention } \\
\text { in Filipino youth behavioral } \\
\text { health dipartites: Identifying } \\
\text { barriers and facilitators to } \\
\text { participating in „Incredible } \\
\text { Years“, and evidence-based } \\
\text { parenting intervention, Los } \\
\text { Angeles, California. } 2012 .{ }^{9}\end{array}$ & $\begin{array}{l}\text { Istraživački rad } \\
\text { ( } N=20 \text { roditelja) }\end{array}$ & $\begin{array}{l}\text { Edukacija o učinkovitom } \\
\text { roditeljstvu, grupna podrška, } \\
\text { edukacija o poboljšanju } \\
\text { odnosa unutar obitelji, } \\
\text { motiviranje na uključivanje u } \\
\text { edukaciju }\end{array}$ & $\begin{array}{l}\text { Intervencije roditelja } \\
\text { mogu smanjiti pojavnost } \\
\text { mentalnih poremećaja } \\
\text { kod mladih. Važno je } \\
\text { poraditi na barijerama koje } \\
\text { onemogućuju roditelje da se } \\
\text { uključe u programe. }\end{array}$ \\
\hline $\begin{array}{l}\text { Schulte-Korne G. Mental } \\
\text { health problems in a school } \\
\text { setting in children and } \\
\text { adolescents. 2016. }{ }^{10}\end{array}$ & $\begin{array}{c}\text { Sistematični pregled } \\
\text { literature }\end{array}$ & $\begin{array}{l}\text { Suradnja s roditeljima, } \\
\text { nastavnicima, zdravstvenim } \\
\text { djelatnicima, intervencije } \\
\text { temeljene na kognitivno- } \\
\text { bihevioralnoj terapiji, } \\
\text { interaktivna nastava, mjere } \\
\text { usmjerene rizičnoj skupini }\end{array}$ & $\begin{array}{l}\text { Jačanje mentalnog zdravlja, } \\
\text { smanjenje psihološkog } \\
\text { pritiska i stresa te smanjenje } \\
\text { slučajeva „bulinga“ i } \\
\text { „mobinga“ bilo je slabo } \\
\text { do umjereno. Univerzalni } \\
\text { program smanjenja nasilja te } \\
\text { smanjenje slučajeva bulinga } \\
\text { i mobinga imao je vrlo malo } \\
\text { efekta. }\end{array}$ \\
\hline $\begin{array}{l}\text { Pophillat EP et al. Preventing } \\
\text { internalizing problems in } 6-8 \\
\text { year old children: a universal } \\
\text { school-based program. } 2016 .{ }^{11}\end{array}$ & Istraživački rad (N = 206) & $\begin{array}{c}\text { Povećanje znanja o } \\
\text { emocijama, učenje o } \\
\text { kontroliranju emocija, } \\
\text { pružanje pomoći kod pojave } \\
\text { straha i gnjeva, učenje o } \\
\text { svjesnosti tuđih emocija, } \\
\text { rješavanje problema u } \\
\text { eksperimentalnoj skupini }\end{array}$ & $\begin{array}{l}\text { Ispitanici u eksperimentalnoj } \\
\text { skupini nisu pokazivali } \\
\text { veće smanjenje simptoma } \\
\text { depresije i anksioznosti u } \\
\text { odnosu na kontrolnu skupinu } \\
\text { (odbijena } 1 \text {. hipoteza) } \\
\text { te provođenje brojnih } \\
\text { intervencija na rizičnu } \\
\text { skupinu ispitanika nije } \\
\text { pokazalo pad poteškoća u } \\
\text { razdoblju nakon testa }\end{array}$ \\
\hline
\end{tabular}


odredili smjernice razvoja programa prevencije nastanka mentalnih poremećaja kod djece i mladih. Zajednički je upravo rad na sustavnom i timskom pristupu te ranom prepoznavanju i liječenju rizične skupine mladih i adolescenata.

Autor Schulte-Korne 2016 godine objavio je popis faktora koji utječu na razvoj mentalnog zdravlja školske djece. ${ }^{10}$ Jedan je od najvažnijih prediktora normalnog zdravlja djece školske dobi osjećaj sigurnosti. Sigurnost obuhvaća socijalnu, emocionalnu i fizičku komponentu koja bi trebala biti zadovoljena. Nasilje u ranoj životnoj dobi ostavlja dugoročne tragove i posljedice. Nasilje među vršnjacima koje se očituje kroz buling ili mobing postalo je čest i javno eksponiran problem. Posljedice nasilja mogu se protezati od trajno narušenog mentalnog zdravlja do nanošenja ozljeda koje su ponekad nespojive sa životom. Važno je unaprijed planirati mjere prevencije te disciplinske mjere. Nadalje, ono što je važan faktor u održavanju mentalnog zdravlja jest osjećaj pripadnosti. Važno je da se pojedinac osjeća kao dio tima te da bude prihvaćen u socijalnom okruženju, što podrazumijeva prihvaćanje među školskim kolegama, prihvaćanje u susjedstvu i tome slično. ${ }^{10}$

Normalno funkcioniranje obitelji, kao i pojedinca u zajednici u kojoj se školuje i živi važan je prediktor normalnog mentalnog funkcioniranja. Dokazalo se kako dobra obiteljska klima, jaka socijalna potpora, kao i osobine pojedinca imaju pozitivan utjecaj na pojavnost mentalnih poremećaja u dječjoj dobi. Osobine su koje imaju pozitivan utjecaj optimizam, samoučinkovitost i osjećaj koherentnosti. Razvijanjem vlastitog identiteta, osjećaja pripadnosti, sigurnosti te pružanjem obiteljske i prijateljske podrške se razvija osjećaj koherentnosti, koji za rezultat ima unaprjeđenje načina nošenja sa stresnim situacijama. ${ }^{25-28}$ Glavne su intervencije timski pristup djeci predškolske i školske dobi s prisutnim rizičnim čimbenicima, rano prepoznavanje rizične populacije, poticanje komunikacije između nastavnika, zdravstvenog osoblja i djece, timski razvoj plana prevencije, sustavno praćenje pacijenta, uključujući liječenje i rehabilitaciju, dogovor oko vrste terapije i pacijentovo prihvaćanje terapije, skrb za svaki aspekt blagostanja i fizičkog zdravlja kod djece i mladih.,8,29,30 Interakcija između nastavnika i učenika također je važan prediktor očuvanja mentalnog zdravlja. Nastavnici također moraju pružiti emocionalnu podršku te prihvatiti odgovornost koja se stavlja pred njih. ${ }^{31,32}$

\section{RASPRAVA}

Svjetska zdravstvena organizacija upozorava kako nema zdravlja bez mentalnog zdravlja. Dakle, sastavi je dio normalnog funkcioniranja u svakodnevnom život sklad između tjelesnog i mentalnog zdravlja. U posljednja dva desetljeća u bolničkom pobolu zbog mentalnih poremećaja bilježi se trend rasta broja i stopa hospitalizacije na ukupno 100000 stanovnika, kao i po spolu.

Prevencija mentalnih poremećaja kod djece i adolescenata i dalje je u razvoju, što uključuje istraživanja i otkrivanje najboljeg pristupa osobama mlađe životne dobi. Kada se govori o prevenciji mentalnih poremećaja odraslih, znano je kako je riječ o dobro istraženom području s brojnim preventivnim programima i zadovoljavajućim rezultatima.

Budući da pojavnost mentalnih poremećaja i vrste mentalnih poremećaja nisu iste s obzirom na dob, važno je odrediti rizične faktore kako bi se ciljano moglo djelovati na specifične rizične faktore. Svrha je rada prikazati dostupne znanstvene članke koji se odnose na promociju mentalnog zdravlja djece i adolescenata. Također, svrha je rada pregledom znanstvenih članaka upozoriti na važnost ranog otkrivanja i liječenja osoba s narušenim mentalnim zdravljem te promocije i zaštite mentalnog zdravlja kod djece i adolescenata.

Programi prevencije od iznimne su važnosti te je potrebno početi s njihovom primjenom u najranijoj dobi. Smatra se da se adekvatno provedenim programom prevencije omogućuje novčane ušteda, kada je riječ o prevenciji ovisnosti (plaćanje liječenja i kaznenog pravosuđa), uz, naravno, daleko veću isplativost za obitelj i zajednicu kojoj pojedinac pripada.

Sredine u kojima je potrebno provoditi program prevencije uključuju obitelj, škole/domove, zajednicu, radno mjesto i zdravstveni sektor. Kada je riječ o djeci i adolescentima, najveći utjecaj ima upravo obitelj i škola, odnosno zajednica. Programi promocije mentalnog zdravlja diljem svijeta obuhvaćaju brojne intervencije te predstavljaju složen, sveobuhvatan i održiv niz aktivnosti koje se provode u obitelji, školama, zajednici, zdravstvenom sustavu i radnom mjestu.

Pregledom znanstvene literature uočeno je kako su predloženi programi, mjere i intervencije podudarni u više zemalja. Programi koji se provode na području SAD-a podudarni su s europskim programima, bez ob- 
zira na različitosti kulture i postojanje različitih barijera u njihovu izvođenju. Navedeno utječe na uspješnost implementacije programa među mladima. Nedostatak edukacije i nemotiviranost u sudjelovanju i pridržavanju preporučenih intervencija glavne su manjkavosti. Važno je napomenuti kako timski rad ima izniman utjecaj u prevenciji mentalnih poremećaja. Suradnja roditelja, nastavnika, zdravstvenih djelatnika (povezanost primarne zdravstvene zaštite i specijalista) s predškolskom i školskom djecom temelj je dobre implementacije programa.

Republika Hrvatska provodi sveobuhvatni program prevencije metalnih poremećaja koji uključuje edukaciju, razvoj i nadogradnju na dokazima i istraživanjima, senzibilizaciju i holistički pristup. Rezultati pretrage, prikazani u tablici 2, ukazuju na to kako su sve preporučene intervencije pronašle svoju primjenu i na području Republike Hrvatske.

Prikazom rezultata pridržavanja preporučenih programa intervencije omogućen je daljnji napredak i razvoj programa. Rezultati nas upućuju na postojanje slabosti koje rezultiraju pojavom različitih mentalnih poremećaja. Jačanje suradnje, kontinuirana edukacija roditelja i djece, jačanje mentalnog zdravlja i smanjenje psihološkog pritiska važni su prediktori održivosti mentalnog zdravlja.

Različiti su autori pregledom literature te provođenjem istraživanja odredili smjernice razvoja programa prevencije nastanka mentalnih poremećaja kod djece i mladih. Zajednički je upravo rad na sustavnom i timskom pristupu te ranom prepoznavanju i liječenju rizične skupine mladih i adolescenata, što je temelj u izradi programa prevencije.

\section{ZAKLJUČAK}

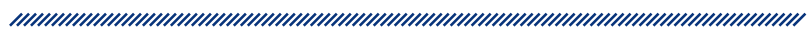

Promocija mentalnog zdravlja djece i adolescenata osigurava adekvatan rast i razvoj te stvara temelje budućih generacija. Programi prevencije moraju se provoditi sustavno, dosljedno i moraju osiguravati holistički pristup. Glavne su smjernice prepoznavanje rizičnih faktora, rani screening oboljelih te uključivanje u skrb roditelje, nastavnike, zdravstveno osoblje i sve dostupne resurse koji su u kontaktu s djecom i adolescentima. $S$ obzirom na sve veću pojavnost mentalnih poremećaja u toj dobi, važna je edukacija roditelja i djece. Unaprijed izrađeni planovi prevencije omogućuju direktno djelovanje na rizične čimbenike na koje se može utjecati, kao što su adekvatan odgoj djece, uravnoteženi obiteljski odnosi, izbjegavanje djece izloženosti fizičkom, emocionalnom i seksualnom zlostavljanju te osiguranje potpore i sigurne okoline u školi.

\section{LITERATURA}

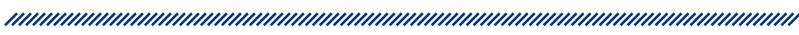

1. HZJZ. Odjel za promicanje mentalnog zdravlja i prevenciju ovisnosti sa savjetovalištem. Dostupno na: http:// www.hzjz.hr/sluzbe/sluzba-za-promicanje-zdravlja/ odjel-za-mentalno-zdravlje-i-prevenciju-ovisnosti/ (pristupljeno 24. lipnja 2016.).

2. Balarin F. Pristup psihičkim poremećajima djece i mladih. Dostupno na: http://www.nzjz-split.hr/web/images/MENTALNO/pristup\%20psih\%20poremecajima\%20djece\%20 ¡\%20mladih.pdf (pristupljeno 24. lipnja 2016.).

3. Rampazzo LM. Joint action on mental health and wellbeing. Mental health and schools. Dostupno na: http:// www.mentalhealthandwellbeing.eu/assets/docs/publications/WP7\%20Final.pdf (pristupljeno 24. lipnja 2016.).

4. Dulmus CN, A.C.S.W, Wodarski JS. Prevention of childhood mental disorders: a literature review reflecting hope and a vision for future. Child Adolesc Social Work J. 1997. 14(3): 181-198.

5. Zubrick SR, Silburn SR, Burton P, Bair E. Mental health disorders in children and young people: scope, cause and prevention. Aust N Z J Psychiatry. 2000; 34: 570-578.

6. Moher D, Liberati A, Tetzlaff J, Altman DG, The PRISMA Group. Preferred Reporting Items for Systematic Reviews and Meta-Analyses: The PRISMA Statement. Ann Intern Med. 2009; 151(4).

7. Patel V, Flisher AJ, Hetrick S, McGorry P. Mental health of young people: a global public-health challenge. The Lancet. 2007; 369: 1302-1313.

8. Catania LS, Hetrick SE, Newman LK, Purcell R. Prevention and early intervention for mental health problems in 0-25 year olds: Are there evidence-based models of care?. Adv Mental Health. 2011; 10: 6-19.

9. Flores $\mathrm{N}$ et al. Prevention of Filipino youth behavioral health disparities: identifying barriers and facilitators to participating in „Incredible Years”, and evidence-based parenting intervention, Los Angeles, California. Preventing chronic disease. 2015; 12: E178.

10. Schulte-Korne G. Mental health problems in a school setting in children and adolescents. Dtsch Arztebl. 2016; 113: $183-190$. 
11. Pophillat EP et al. Preventing internalizing problems in 6-8 year old children: a universal school-based program. Front Psychol. 2016; 7.

12. Vlada Republike Hrvatske. Nacionalna strategija za prava djece u Republici Hrvatskoj od 2014. do 2020. 2014. Dostupno na: https://vlada.gov.hr.

13. Švab V. Obravnava v skupnosti. Ljubljana, Slovenija: Šent Slovensko združenje za duševno zdravlje, 2015.

14. Nastavni zavod za javno zdravstvo dr. Andrija Štampar. Očuvanje mentalnog zdravlja. Dostupno na: http://www. stampar.hr/hr/ocuvanje-mentalnog-zdravlja (pristupljeno 8. srpnja 2016.).

15. Watkins KE, Burnam MA, Okeke EN, Setodji CM. Evaluating the Impact of Prevention and Early Intervention Activities on the Mental Health of California's Population. Rand Corporation, 2012.

16. Hohmann S, Adamo N, Lahey BB, Faraone SV, Banaschewski T. Genetics in child and adolescent psychiatry: methodological advances and conceptual issues. Eur Child Adolesc Psychiatry. 2015; 24: 619-634.

17. Boring JL, Velez CE, Sandler IN, Tein JY, Horan JJ. Children of divorce-coping with divorce: a randomized control trial of an online prevention program for youth experiencing parental divorce. J Consult Clin Psychol. 2015; 999-1005.

18. Kendall PC, Cummings CM, Villabo MA et al. Mediators of change in the child/adolescent anxiety multimodal treatment study. J Consult Clin Psychol. 2015; 84: 1-14.

19. Lewandowski RE Acri MC, Hoagwood KE et al. Evidence for management of adolescent depression. Pediatrics. 2013; 132: 996-1009.

20. Hrabak-Žerjavić V, Silobrčić Radić M, Folnegović-Šmalc V, Mimica N. Javnozdravstveno značenje depresivnih poremećaja. Medicus. 2004; 13: 11-17.

21. Henderson J. The national mental health strategy: redefining promotion and prevention in mental health. Australian Journal of Primary Health. 2007; 13: 78-84.

22. Schmidt RC, lachini AL, George M, Koller J, Weist M. Integrating a suicide prevention program into a school mental health system: a case example from rural school district. Children and School. 2014; 37: 18-26.
23. Story CR, Kirkwood AD, Parker S, Weller B. Evaluation of the Better Todays / Better Tomorrows youth suicide prevention program: increasing mental health literacy in rural communities. Best Practices in Mental Health. 2016; 12: 14-25.

24. Evans ME, Bruns EJ, Armstrong MI, Hodges S, Hernandez M. New frontiers in building mental, emotional and behavioral health in children and youth: introduction to the special section. Am J Orthopsychiatry. 2016; 86: 103-108.

25. Waring T, Hazell T, Hazell P, Adams J. Youth mental health promotion in the Hunter region. A NZ J Psychiatry. 2000; 34: 579-585.

26. Hall AS, Tornes I. Partnerships in preventing adolescent stress: increasing self- esteem, coping, and support effective counseling. J Ment Health Couns. 2002; 24: 97-109.

27. Schlack R, Petermann F. Prevalence and gender patterns of mental health problem in German youth with experience of violence: the KiGGS study. BMC Public Health. 2013; 13: 628.

28. Gallegos J, Linan-Thompson S, Stark K, Ruvalcaba N. Preventing childhood anxiety and depression: testing the effectiveness of a school based program in Mexico. Psihologia Educativa. 2013; 1: 37-44.

29. Gallegos J, Benavides R, Beretvas T, Linan-Thompson SL. Psychosocial interventions to prevent anxeity disorders in school settings from 1985 - 2007: A meta-analysis. Psihologia Educativa. 2012: 18: 41-51.

30. Vandiver V. Integrating health promotion and mental health: an introduction to policies, principles and practices. Oxford University Press; 2009.

31. Gigantesco A, Del Re D, Cascavilla I, et al. A universal mental health promotion programme for young people in Italy. BioMed research international. 2015; 2015.

32. Patel V, Woodward A, Feigin HK, Heggenhougen HK, Quah S. Mental and neurological Mental Health. Elsevier Inc.; 2008. 


\section{PROMOTION OF MENTAL HEALTH AND PREVENTION OF MENTAL DISORDERS IN CHILDREN AND ADOLESCENTS - A SYSTEMATIC LITERATURE REVIEW}

1 Ledinski Fičko Sanja

1 Snježana Čukljek

1 Martina Smrekar

1 Ana Marija Hošnjak

1 Department of Nursing, University of Applied Health Sciences, Zagreb

\section{ABSTRACT}

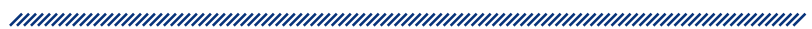

Objective: The prevalence of mental disorders increases in children and adolescents, and it is a major challenge for public health protection. Mental health disorders are numerous and they include the occurrence of depression, intellectual disability, and other risk behaviors. According to the latest data, $10-20 \%$ of children and adolescents suffer from one of the mentioned disorder. The aim of this study is to review the available scientific literature and to examine methods of promotion of mental health in children and adolescents.

Methods: A systematic literature review was based on a review of available scientific papers. The studies which have entered the final stage of processing, have been published as a systematic review of the literature and researches, they are derived from the MEDLINE database and are written in English.

Results: There are numerous of national programs carried out to promote the mental health of children and adolescents, but regardless of the implementation of these programs, there is a high incidence of mental disorders at a young age. It is important to strengthen cooperation between primary health care and specialists and the conduct of specific interventions witch refer to risk factors that occur.

Conclusion: Promotion of mental health of children and adolescents ensures adequate growth and development and forms the basis for future generation. Prevention programs must be carried out systematically, consistently and should provide a holistic approach. Given that the incidence of mental disorders in children and adolescents increases, education of children and their parents is important. Pre-made prevention plans allow direct effect on the risk factors.

Keywords: mental health, prevention, promotion, children and adolescents, risk factors 